\title{
Using the Kaban Lakes Integrated Assessment Model for Investigating Potential Levels of Antibiotic Pollution of the Nizhniy Kaban and Sredniy Kaban Lakes
}

\author{
Liudmila L. Frolova • Antoniy Elias Sverdrup • \\ Harald Ulrik Sverdrup (D)
}

Received: 4 March 2020 / Accepted: 13 July 2020 / Published online: 5 August 2020

(C) The Author(s) 2020

\begin{abstract}
The Kaban Lakes Integrated Assessment Model (KLIAM) was enhanced in order to assess the possible content of antibiotics in the Kaban lakes, located within the city borders of Kazan City, Tatarstan Republic in the Russian Federation, and potential for adverse environmental effects. The Kaban Lakes Integrated Assessment Model simulations suggest that the concentrations in the Nizhniy Kaban lake and Sredniy Kaban lake may exceed the predicted no effect concentration (PNEC) and low-risk limits set by EU and the WHO. Many missing data could be assumed or approximated, and simulation runs were conducted. The results are consistent with other global studies in terms of average concentrations observed elsewhere in rivers and lakes. The results suggest that the study should be followed up with lake water analysis and an assessment of antibiotic loads to the Kaban lakes. It is concluded that the results are too uncertain to initiate any policy
\end{abstract}

\footnotetext{
L. L. Frolova · A. E. Sverdrup

Genetics and Bioinformatics, Kazan Federal University, Kremlevskaya Street 18, Kazan, Tatarstan Republic, Russian Federation 420008

H. U. Sverdrup

Gamification and Systems Thinking, Inland University of Applied Sciences, 2315 Hamar, Norway

H. U. Sverdrup $(\bowtie)$

Industrial Engineering, University of Iceland, Hjardarhagi 2-6, 107 Reykjavik, Iceland

e-mail: harald.sverdrup@inn.no
}

action at the present moment and that an assessment supported by measurements would be warranted.

Keywords System dynamics · Supply · Sustainability · Kaban lakes · Antibiotics

\section{Introduction}

The Kaban lakes are located within the city limits of Kazan, Russia, and they are the largest natural lakes in the Tatarstan Republic. They are important parts of the city landscape and important resource for the recreation resources of the city. They are located in a pleasant environment, and a redevelopment of the area surrounding the Kaban lakes is planned for the next decade. The Kaban lakes have been eutrophic for a long time because of a long history of industry pollution and sewage flowing freely from the city to the Kaban lakes. Kazan earned itself a reputation for having bad water, something the can still noticed in the inhabitants habits by an outsider (Vishlenkova 2005). The Kaban lakes still suffer from this, and more professional efforts are needed to improve the water quality of the Kaban lakes, such as making swimming and bathing a pleasant experience or getting tap water to have stable drinking water quality. Table 1 shows some data describing the Kaban lakes. The Kaban lakes are frozen over by ice from December to the end of March. The Kaban lakes experience a typical continental climate, with warm summers $\left(25{ }^{\circ} \mathrm{C}\right.$ to $\left.30{ }^{\circ} \mathrm{C}\right)$ and cold winters $\left(-10{ }^{\circ} \mathrm{C}\right.$ to $\left.-35^{\circ} \mathrm{C}\right)$. There is a lot of urban development around the Kaban lakes. Both 
Table 1 Hydrological and physical characteristics of the Kaban lakes, Kazan, Russia

\begin{tabular}{|c|c|c|c|c|c|c|c|}
\hline Object & $\begin{array}{l}\text { Lake area } \\
\left(\mathrm{km}^{2}\right)\end{array}$ & 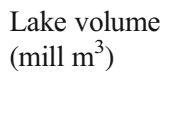 & $\begin{array}{l}\text { Average } \\
\text { depth }(\mathrm{m})\end{array}$ & $\begin{array}{l}\text { Max } \\
\text { depth } \\
\text { (m) }\end{array}$ & $\begin{array}{l}\text { Inflow (mill } \\
\mathrm{m}^{3} \mathrm{yr}^{-1} \text { ) }\end{array}$ & $\begin{array}{l}\text { Average water } \\
\text { residence time (yr) }\end{array}$ & $\begin{array}{l}\text { Catchment } \\
\text { size }\left(\mathrm{km}^{2}\right)\end{array}$ \\
\hline Nizhniy Kaban lake & 0.456 & 3.82 & 8.4 & 17.3 & $4.88^{1}$ & 0.59 & 9.68 \\
\hline Sredniy Kaban lake & 1.313 & 10.01 & 6.4 & 19.0 & $24.35^{1}$ & 0.39 & 38.63 \\
\hline $\begin{array}{l}\text { Channel from Sredniy Kaban lake } \\
\text { to Nizhniy Kaban lake }\end{array}$ & 0.064 & 0.16 & 2.5 & 4.4 & $\begin{array}{l}4.00^{2} \\
1.56^{3}\end{array}$ & 0.04 & 1.10 \\
\hline Bulak channel & 0.032 & 0.02 & 0.65 & 0.8 & $0.63^{4}$ & 0.03 & 1.30 \\
\hline $\begin{array}{l}\text { Pump to Kazanka from Nizhniy } \\
\text { Kaban lake }\end{array}$ & - & - & - & - & 5.31 & - & - \\
\hline $\begin{array}{l}\text { Pump to Volga from Sredniy } \\
\text { Kaban lake }\end{array}$ & - & - & - & - & 6.95 & - & - \\
\hline
\end{tabular}

${ }^{1}$ From the catchment, ${ }^{2}$ between the lakes, ${ }^{3}$ net water exchange, ${ }^{4}$ Bulak catchment input

Kaban lakes have been and are still exposed to the kind of pollution that comes from an urban-industrial environment and a highly populated area. This implies very bioactive substances like medications and endocrine disruptive substances, as well as urban dust, hydrocarbons from vehicles, and leakage from city sewage (Laxminarayan et al. 2013). The rate of discovery of new antibiotic substances is declining after 1980 (Sverdrup et al. 2020).

\section{Objectives and Scope}

The objective is to use the process-oriented model system Kaban Lakes Integrated Assessment Model (KLIAM) model for investigating possible antibiotic pollution in the Nizhniy Kaban and Sredniy Kaban lake system. This model tool will be used to develop different aspects of the Kaban lake management plan and measures to be taken. The model will have predictive capability, in order to be able to forecast possible outcomes of measures taken in the lake catchments and in the lakes themselves. The KLIAM model should be able to handle short-term variations (within a year) and longterm aspects (100-200 years). Antibiotic pollution in waterways is a global problem, in particular where big rivers pass through large population centers (Gilbert 2019; Boxall and Wilkinson 2019; Wilkinson and Boxall 2019; Behdinan and Hoffmann 2015; Laxminarayan et al. 2013), but a small river or lake (Kaban lakes) in a big city (Kazan) will most probably share the same type of issues. We intend to assess if this is relevant for the Kaban lakes system. During the last two decades, antibiotic use in Russia has increased significantly towards Central European levels (van Boeckel et al. 2014; Moisenko 1994, Obukhova and Lartseva 2014, 2018, Gabdulhakova et al. 2016). The small lake Verkhniy Kaban lake to the south of the Sredniy Kaban lake is separated from these lakes hydrologically and will not be addressed in this study.

\section{Methods}

This paper closely follows a publication in Water, Air, Soil Pollution by the same authors (April 2020): Using a System Dynamics Model for Investigating Potential Levels of Antibiotics Pollution in the Volga River $(\mathrm{H}$. U. Sverdrup, L.L. Frolova, A.E. Sverdrup), Water Air Soil Pollut 2020; 231:173 (https://doi.org/10.1007 /s11270-020-04526-w). For modeling of the eutrophication of lakes, we follow the state-of-the-art methods (Chapra 1991; Chapra and Reckhow 1983; Barkman and Sverdrup 1994; Barkman et al. 1994; Aldeyab et al. 2008; Heberer et al. 1998). The methodology used here uses systems analysis for conceptualization, as the preparation for building a simulation model using the STELLA software. KLIAM is a system dynamics model for the environmental status of lakes in cultural landscapes. The main standard methods of systems analysis and system dynamics modeling are used (Albin 1997, Forrester 1971, Meadows et al. 1974, Roberts et al. 1982, Senge 1990; Senge et al. 2008; Haraldsson and Sverdrup 2005; Haraldsson 2004; Binder et al. 2003; Sverdrup et al. 2018). We analyze the system using stock-and-flow charts and 
causal loop diagrams. The mass balance expressed differential equations resulting from the flow charts and the causal loop diagrams will be numerically solved using the STELLA ${ }^{\circledR}$ modeling environment (Kim 1992 ; Senge 1990; Haraldsson 2004; Haraldsson and Sverdrup 2005; Sverdrup et al. 2018). A system dynamics model forces a compilation of the known data for the lake system and relates them to each other in a consistent way using mass balances and changes in stocks and flows. It forces the system model to be mass balance consistent and works with causal relationships. A different scheme would be statistical approaches, but then it must be remembered that correlation is not necessarily causation. Statistical approaches have limited prediction capability and thus have limited use in future planning. With a causality-based, mass balance consistent simulation model, possible future outcomes can be studied (Roberts et al. 1982; Chapra and Reckhow 1983). With a causal model structure, the real causal factors behind a pollution problem may be addressed. This is not done with the same robustness with a statistical approach.

The global tonnage of antibiotic substance production and predicted future production was taken from Sverdrup et al. (2020) using data from Davies and Davies (2010); Allen et al. (2010); van Boeckel et al. 2014, 2015); Klein et al. (2017); World Health Organization (2015a, b), 2017); Emerson de Lima Procopio et al. (2012); and Sarmah et al. (2006). The antibiotic use projections were derived from the World Health Organizations scenarios (2015a, b; 2017).

\section{On Antibiotics}

Antibiotics began with the discovery of penicillin in 1928 (Fleming 1929; Gaynes 2017) in Great Britain and sulfonamide (Domagk 1935) in 1932 in Germany. This changed the success of the treatment of bacterial infections dramatically (Tan and Tatsumura 2015). The substance used is specific for the microorganism and with limited toxicity to humans (Andersson 2006, Gualerzi et al. 2013, Cassir et al. 2014; Gore 2015; Hurd et al. 2004, Leekha et al. 2011, Phillips et al. 2003, Shea 2003, Tan and Tatsumura 2015, Ventola 2011, Zaffiri et al. 2012; Ling 2015). The rate of development of antibiotics has dropped since the 1980s, and the number of effective antibiotics has dwindled significantly in the subsequent years. As the resistance increases, the number of infectious cases that can be treated will dwindle.
In 2013, a total of $131,000 \mathrm{mt}$ of antibiotic substances were used worldwide in agriculture, while the total production of antibiotic substances was about 167,000 mt (Sverdrup et al. 2020), leaving 66,000 t for human use. The implication is that $78 \%$ of all antibiotics produced in 2013 were used in agriculture, mostly for "growth promotion" (WHO 2015a, b; 2017). Antibiotic production is projected to reach $200,000-350,000$ t per year by 2030 (Davies and Davies 2010; Allen et al. 2010; van Boeckel et al. 2014; 2015; Klein et al. 2017; WHO 2015a, b; 2017). The data on antibiotic usage and production is difficult to find, and the accuracy remains largely unknown.

The available data suggests that $80 \%$ of all antibiotics are used in food production (WHO 2015a, b, 2017). For rural animal husbandry on small-scale farms based on natural grazing, antibiotics in animal husbandry are not needed. Antibiotic need increases in the setting of animal crowding and industrial rearing practices in order to avoid infections under what in reality are unsustainable conditions for the animals. Antibiotics are also used to eliminate microbial competition for food substrates in pigs and chickens, so-called "growth promoters." Meat from farms using antibiotics will contain residual antibiotics, which poses a potential risk for developing microbial antibiotic resistance (Ceccini et al. 2015; Fair and Tor 2014; Ventola 2011, WHO 2015a, b, 2017, Interagency Coordination Group on antimicrobial resistance 2019; Greenfield et al. 2018; HallingSørensen et al. 1998; Heinemann et al. 2000). The input data situation on both types of antibiotics and amounts is problematic, with limited information published. We have leaned on what we could find in the WHO and EU reports to a significant degree and the preparations we did for the earlier study (Sverdrup et al. 2020). Thus, a general antibiotic product mix similar to Central and Eastern Europe was assumed. This is explained in the earlier study (Sverdrup et al. 2020). There are many ways in which antibiotics end up in the environment and in waterways and drinking water:

1. The use of antibiotics in medical treatment of infections, exiting with excrements and urine, enters the sewage (ANSES 2011; Ashton et al. 2004; Brown and Nathwanu 2005).

2. Old medications are sometimes put in to garbage and find its way to landfills (ANSES 2011; Ashton et al. 2004).

3. Medications get flushed down the toilet, ending up in the sewage (Ashton et al. 2004; Castiglioni et al. 
2006; Lyons 2014; Vieno et al. 2005; Woolhouse et al. 2015; Paxéus 2004).

4. Most antibiotics are used in agriculture; human use is the less significant overuse. This occurs with industrialized cattle feedlots, poultry, and pork production and more recently, also in industrialized salmon fish farming (Aarestrup et al. 2001; Aherne et al. 1990; Alder et al. 2006; van Boeckel et al. 2014, 2015, van Bunnik and Woolhouse 2017; Chee-Sanford et al. 2009; Cogliani et al. 2011, Economou and Gousia 2015; Gilchrist 2006; Heilig et al. 2002, Marshall and Levy 2011, Zurek and Ghosh 2014, Higuera-Llantén et al. 2018; Wegener 2003, 2012). The antibiotics end up in the manure contaminate food and enter the human food chain (Landers et al. 2012; Phillips et al. 2003; Shea 2003; Silbergeld et al. 2008; WHO 2009; 2011).

The development of antibiotic resistance is a very serious problem for modern health care, and the threat is near and very substantial in terms of potential loss of life (Belkova et al. 2013; Cassini et al. 2019; Davies and Davies 2010; de Kraker et al. 2016; Penesyan et al. 2015; Podolsky 2018; Price et al. 2015; Watkinson et al. 2007, 2009). The flow chart for stock of effective antibiotics and lost antibiotics to resistance was taken from Sverdrup et al. (2020). A part of the lost may possibly be salvaged by keeping them out of use for 100 years (Sverdrup et al. 2020).

\subsection{Analyzing the Situation}

The pathways for antibiotic substances in human medical use and in agricultural commercial use were taken from Sverdrup et al. (2020). There is leakage from human use to the natural environment through the waste disposal system. More than half of all raw sewage is never ever treated in any way. From agricultural use, antibiotics leak to rivers, lakes, soils, and oceans, and there is almost no treatment of effluents ever anywhere. The agricultural use is 4 times larger than all human uses. The use of antibiotics in society is driven by a number of reinforcing loops. These have been shown in Fig. 1. The first loop is marked with R1. Indicated with R2 is a reinforcing loop driven by economic incentives, running over increased animal production, more profits, more antibiotic demand, and more antibiotic usage in agriculture. The efficient treatment of infections spurs more use to create more successful medical cures. As microorganisms develop antibiotic resistance, more antibiotic substances are developed and the system kept running (R3). However, it was soon found out that the use of antibiotics would increase fodder yield and production rates in animal production. This leads to higher profits, which has been a strong drive for more antibiotic use in meat production (R5). This has led to political lobbying to prevent legislation that would limit the antibiotic use (R4). Finally, the resistance problem is made substantially worse by antibiotic pollution in addition to massive use on animals, forming many balancing loops in the system. The standard type of wastewater treatment is not very effective in reducing antibiotics in sewage water. Once specialized wastewater treatment is introduced, a balancing loop is created. B1 and B2 are the policy loops, where the observation of adverse pollution leads to political lobbying, legal regulation, and technical measures ending up with less antibiotics in the water. B3, B4, and B5 are the balancing loops where more use leads to more resistance, leading to having less effective antibiotics available.

\section{Model Description}

Figure 7 shows an overview of the hydrological flows in the system. Data for the system is shown in Table 1. The lakes are characterized by their short water retention times, less than a year in all of them. The Nizhniy Kaban lake and Sredniy Kaban lake are connected with the Bulak channel (Krestovnikov 1870; Filtzer 2008; Vishlenkova 2005; Kalimullin 2005; Kalimullin and Vinogradov 2015; Mingazova 1999; Mingazova et al. 2019; Derevenskaya et al. 2015). The simulation model has several main parts (Fig. 5):

1. The hydrological module

2. The chemistry model where phosphorus, nitrogen, alkalinity, and particle matter dynamics is calculated

3. The biology module where the plankton dynamics is calculated

4. The oxygen module where the oxygen saturation in the lake is simulated

5. The city pollution inputs to the Kaban lakes

6. The environmental impacts assessment module

Inside each box in the diagram, a model is situated. Each lake module includes inflow from the catchment, flow between the lakes, outflow to Volga River, and pumping to Kazanka River from Nizhniy Kaban lake 


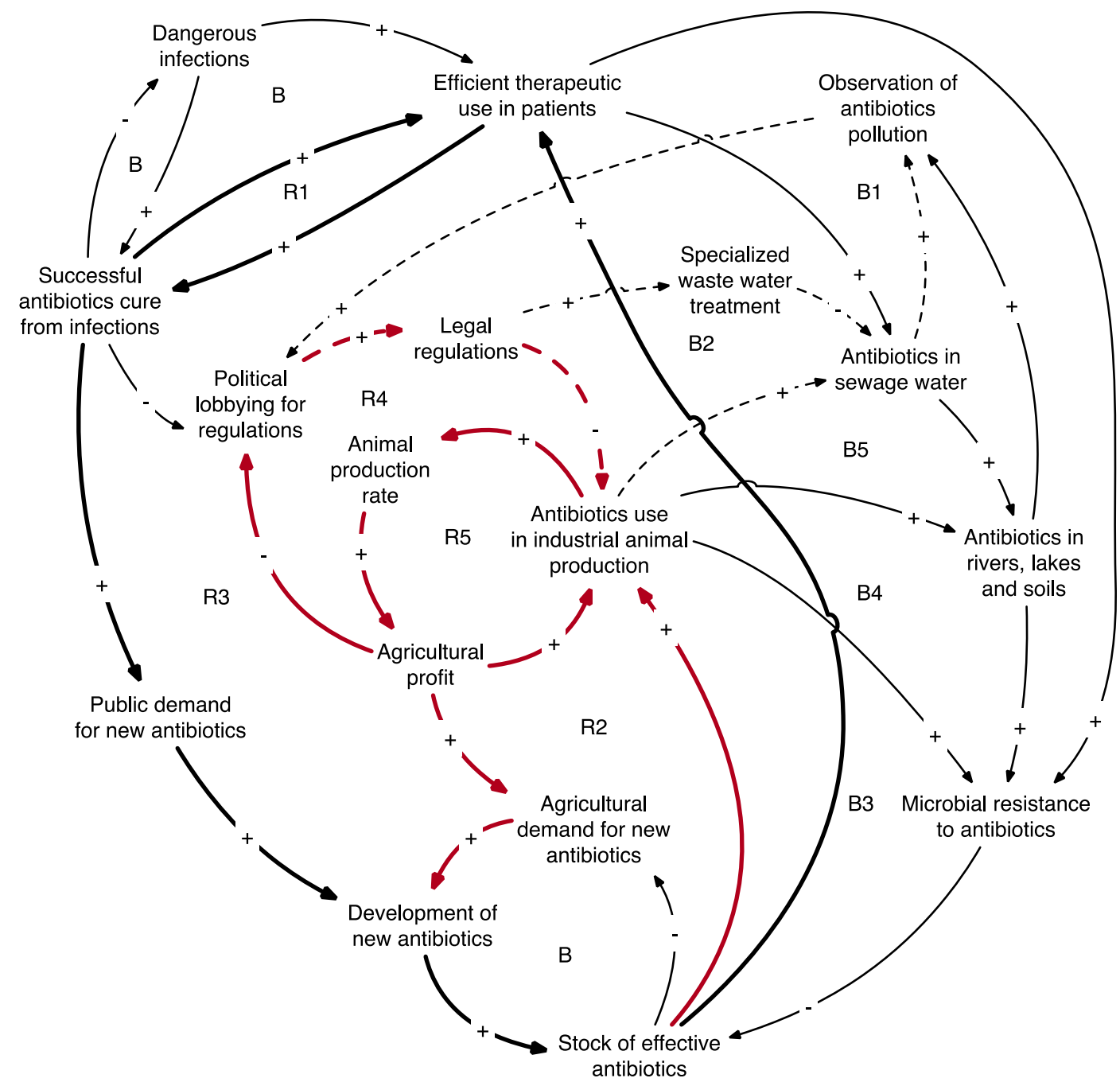

Fig. 1 A causal loop diagram for the problem discussed in the text. Five reinforcing loops (R1-R5) keeps the system running (modified from Sverdrup et al. 2020). Policy acts through 5 linked retarding feedback loops (B1-B5)

and pumping to Volga from Sredniy Kaban lake. The pumping is done to control level variations in the lake (Mingazova 1999; Mingazova et al. 2019; Derevenskaya et al. 2015). There is a natural outflow from Sredniy Kaban lake to Volga. The normal height over the sea is $52 \mathrm{~m}$ for Sredniy Kaban lake, and Volga is on the average 49-m above sea level. That may however vary with about 2-m up or down, depending on the seasons. Water is also pumped from Nizhniy Kaban lake to the Kazanka River. There is no natural outlet from Nizhniy Kaban lake to the Kazanka River at present.

Figure 2 shows the Nizhniy Kaban lake seen towards the Kazan city center around the year 2000. The city is now embedded in the city, but 200 years ago (1800), the area was a rural countryside. A hundred years ago
(1900), the lake had meat procession plants and heavy industry on its shore lines (Dunaev 1833).

Figure $3 \mathrm{a}$ and $\mathrm{b}$ shows the Sredniy Kaban lake as seen from the air. Note that the water is green due to a high concentration of plankton and algae in the lake water. There is a lot of urban development and industries around the lake. Both lakes are exposed to the kind of pollution coming from an urban-industrial environment and a highly populated area. The land use around the lakes has changed a lot over time, from a rural agricultural type to an industrial type, and then been partly deindustrialized and become more residential urban. In earlier times, the lake area had a lot of farms and meat industry (Krestovnikov 1870; Vishlenkova 2005; Mingazova 1999; Mingazova et al. 2019; Derevenskaya 


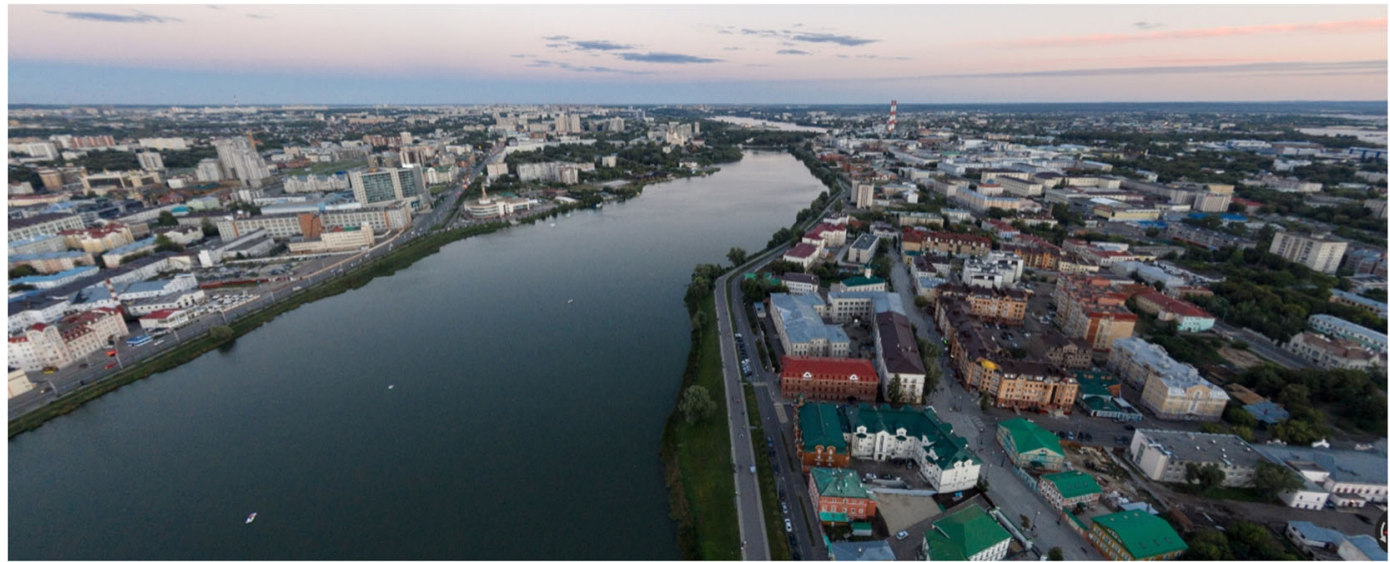

Fig. 2 The Nizhniy Kaban lake seen towards the Kazan city center (2000)

et al. 2015; Gorelits and Zemyanov 2017), which since has been decreased as the area has been redeveloped in modern times. The data available was semiquantitative.

Water flow in the lakes is a combination of both natural flow and in modern times by management by pumping. The capacity of both the pumps at the Nizhniy
Kaban lake and at the outlet of the Sredniy Kaban lake has been reported to be 25 million $\mathrm{m}^{3}$ per year. The peak pump performance is unknown to us but probably in the range of $0.77-1 \mathrm{~m}^{3} / \mathrm{s}$ (Fig. 4).

The antibiotic loads to the lakes are not known and have never been measured. We made a suggestion for a
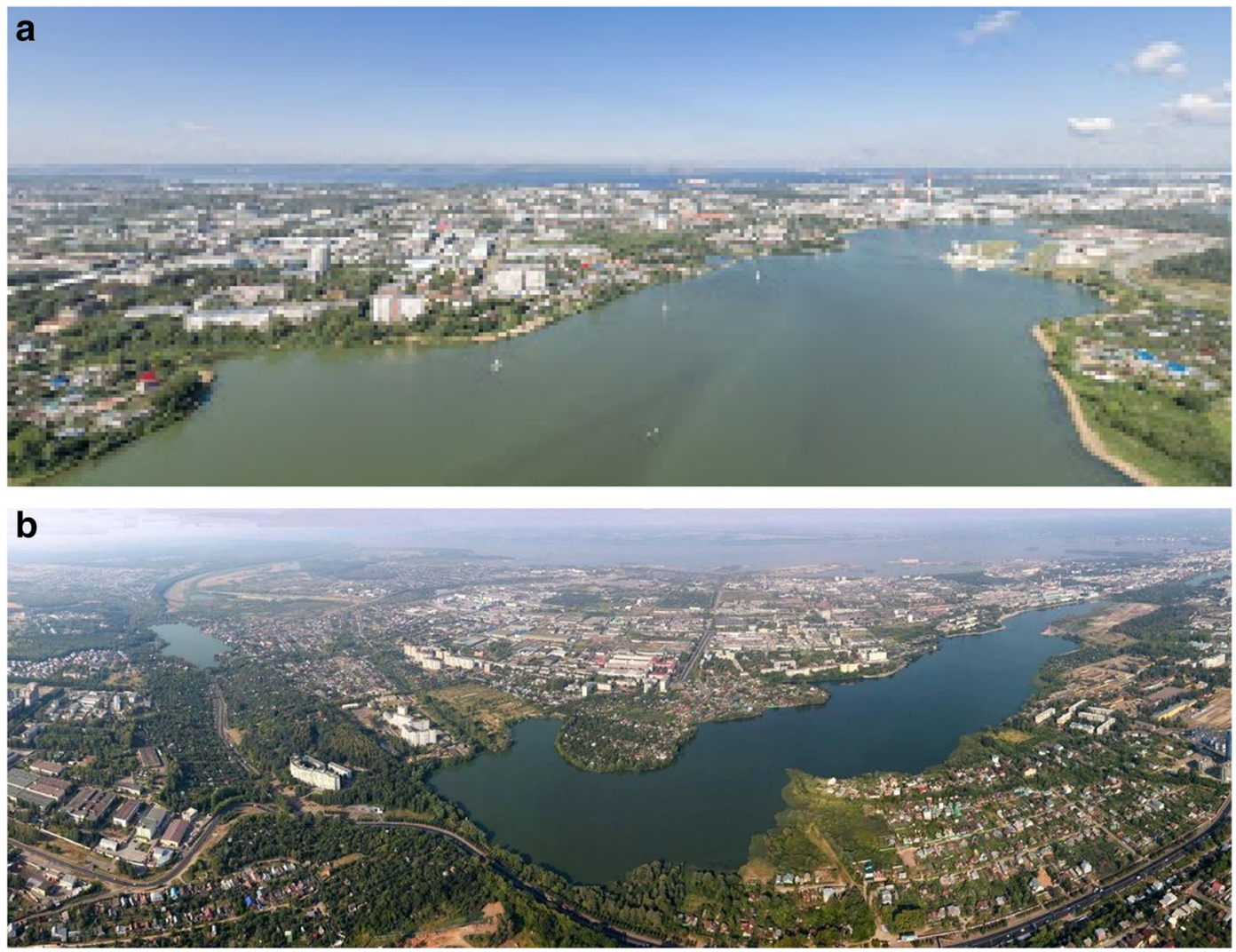

Fig. 3 a The Sredniy Kaban lake seen towards the Kazan city center around the year 2000. An algae bloom is visible in the water. b The Sredniy Kaban lake as seen from the air. The catchment is at present dominated by an urban landscape 
Fig. 4 Overview of the hydrological flows in the system. White is the city landscape, and green is a more rural setting. Large parts of the inflow from the catchment go through underground canalization before it reaches the lakes. The natural flow from Nizhniy Kaban lake to Kazanka River through the Bulak channel stopped when the Kuybyshev dam on the Volga River was ready (Sverdrup et al. 2020) (Fig. 6).

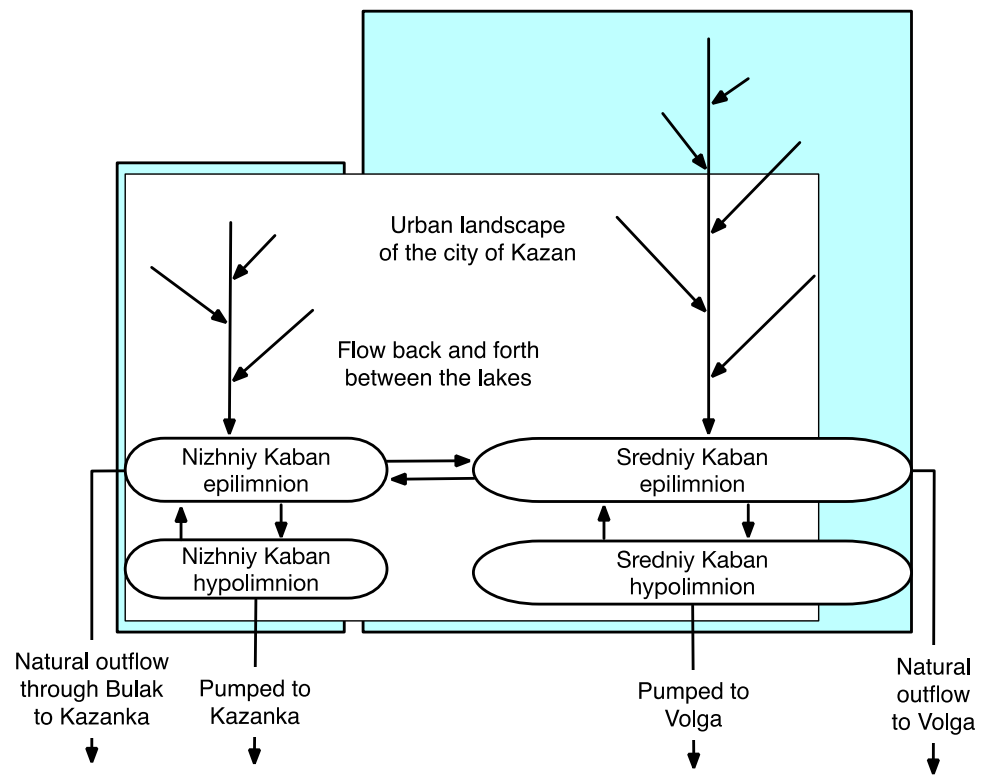

load, based on the fact that each cure takes $500 \mathrm{mg}$ every day, lasting for 14 days (WHO 2011; Fokin et al. 2011; Ratchina et al. 2009; Ratchina 2015; Sverdrup et al. 2020).

This was combined with data for infection incidence, measured, assumed, and guessed, and how many of those that would get antibiotics treatment (WHO 2011; Sverdrup et al. 2020). This was backchecked on general statistics on per capita use of antibiotics in Russia per capita (van Boeckel et al. 2014; Fokin et al. 2011; Ratchina et al. 2009; Ratchina 2015). The mass balance for the lakes used in the model for antibiotic substances is (Sverdrup et al. 2020):

$$
\begin{aligned}
& \text { inflow }+ \text { sediment desorption } \\
& \begin{aligned}
= & \text { accumulation }+ \text { decomposition } \\
& + \text { sediment adsorption }+ \text { outflow } \\
& + \text { sedimentation }
\end{aligned}
\end{aligned}
$$

Inflow is water inflow times the concentration in it; accumulation is the increase in the lake water stock; sorption is adsorption to organic matter in the sediments; decomposition is microbial decomposition in the water by microorganisms; desorption is when the organic matter in the sediments releases adsorbed antibiotics to the water body; and sedimentation is when antibiotics follow dead plankton to the bottom. Some of the antibiotics will desorb to organic matter and slowly release again back into the water. Some will be buried in the sediments. The rate of decomposition of antibiotics is given by the equation (Sverdrup and Stjernquist 2002; de Vries et al. 1998; Chapra 1991):

$\mathrm{r}=\mathrm{k}_{\text {Decomp }} *[$ antibiotics $] * \mathrm{~V} * \mathrm{f}(\mathrm{T})$

The decomposition rate coefficient $k_{\text {Decomp }}$ was set as an average based on the most used antibiotics reported in the available literature (Cycon et al. 2019). $V$ is the lake volume, and $f(T)$ is a function adjusting the rate when the temperature changes. The total intake of antibiotic substances for Russia in general was available. Ratchina et al. 2009, Ratchina 2015) reports DDD = 15,000 international units per 1000 persons. This is supported by the studies of Fokin et al. (2011), Belkova et al. (2013), and ESAC (2009). We have made approximate estimates, based on this best available information (Figures 5, 6 and 7).

The input from the human population and the agricultural activities in the Kaban lake catchments in our first approximation was done using the expression:

Antibiotics input Lake catchment
$=$ Medical input + Agricultural input

The medical input was determined using the following formula: 


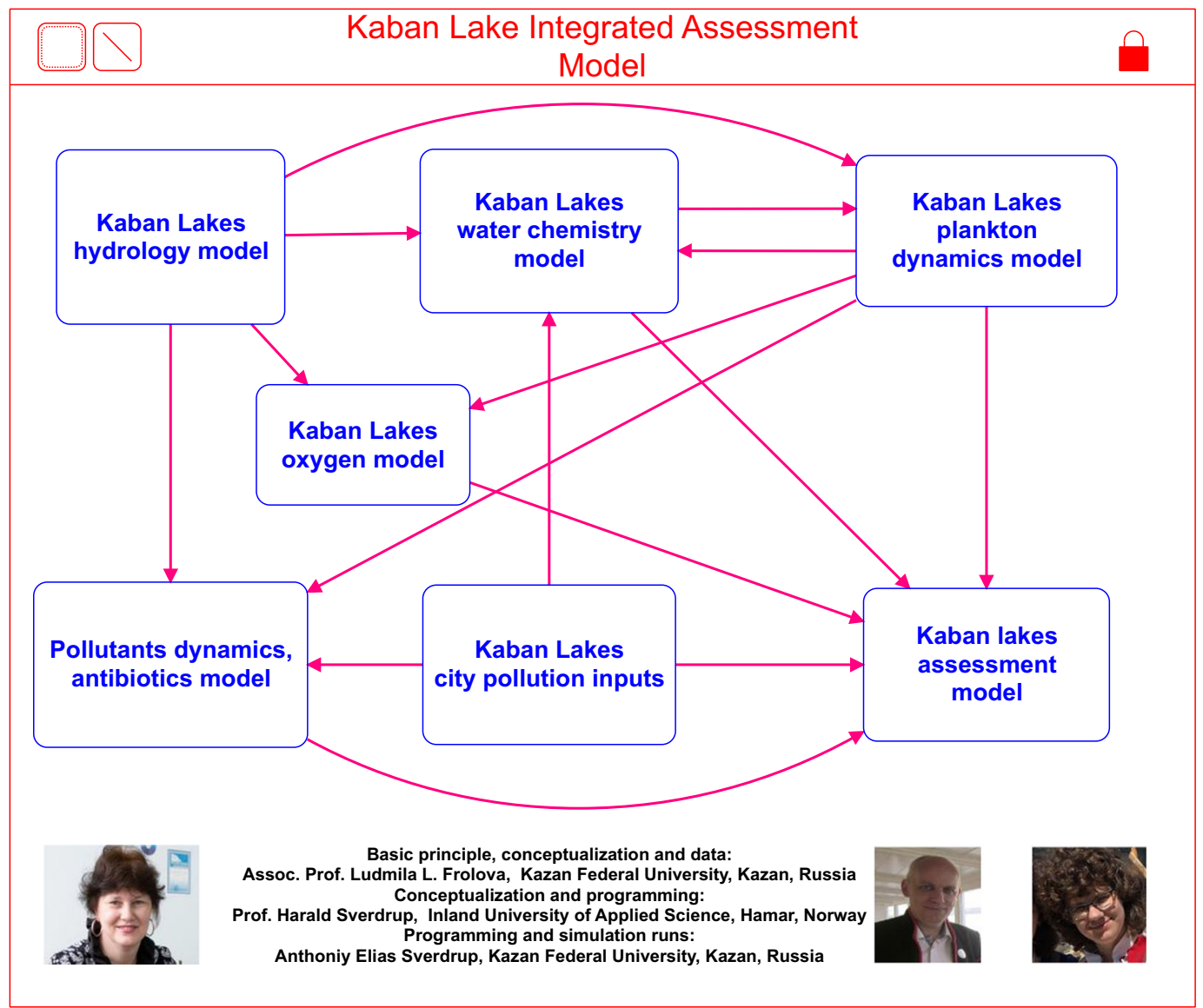

Fig. 5 Overview of the modularized model in the STELLA Architect software

Medical input ${ }_{\text {Lake catchment }}$

$$
=\mathrm{DDD} * \mathrm{P}_{\text {Lake catchment }} * \mathrm{~S}
$$

where $D D D$ is the dose per inhabitants (for Russia, we have set at a maximum $\mathrm{DDD}=15$ dosages per person per year in 2010, based on Ratchina et al. 2009, Ratchina 2015) and Fokin et al. (2011). Before then, it is scaled up (Fig. 8e). $P$ is the population in the catchment which is a varying fraction of the total population in Kazan, one for Nizhniy Kaban lake and one for Sredniy Kaban lake, and $S$ is the dosage strength, which varies a lot between the different substances and that we have set at $\mathrm{S}=500 \mathrm{mg}(500 \mathrm{mg} / \mathrm{DDD})$. The agricultural input to the lake is determined by how much is used in agriculture minus what is decomposed in the soil on the way to the lake. We assume in the model that this transition through the soils takes on the average 7 years (Chapra 1991, Bakker et al. 1998, Sverdrup et al. 2020):
Agricultural input $_{\text {Lake }}$

$=$ Agricultural use-- soil decomposition

We have assumed based on Swedish experience that $5 \%$ of the antibiotics transported drain from the first soil compartment and straight to the runoff that reaches Sredniy Kaban lake (Walse et al. 1998; Sverdrup et al. 2002; Sverdrup et al. 2020). The antibiotics used in agriculture are to a large degree transported with water through the soil before they reach the river. We have a two-stage soil model, where the first stage takes 2 years to pass and the second 5 years for the antibiotics to pass. During these times, the antibiotics in the soil decompose, fast and slow, depending on the temperature (Chapra 1991, Chapra and Reckhow 1983, Bakker et al. 1998, de Vries et al. 1998, Walse et al. 1998, Sverdrup et al. 2002). The literature is not in agreement if adsorbed antibiotics decompose or if that only occurs 


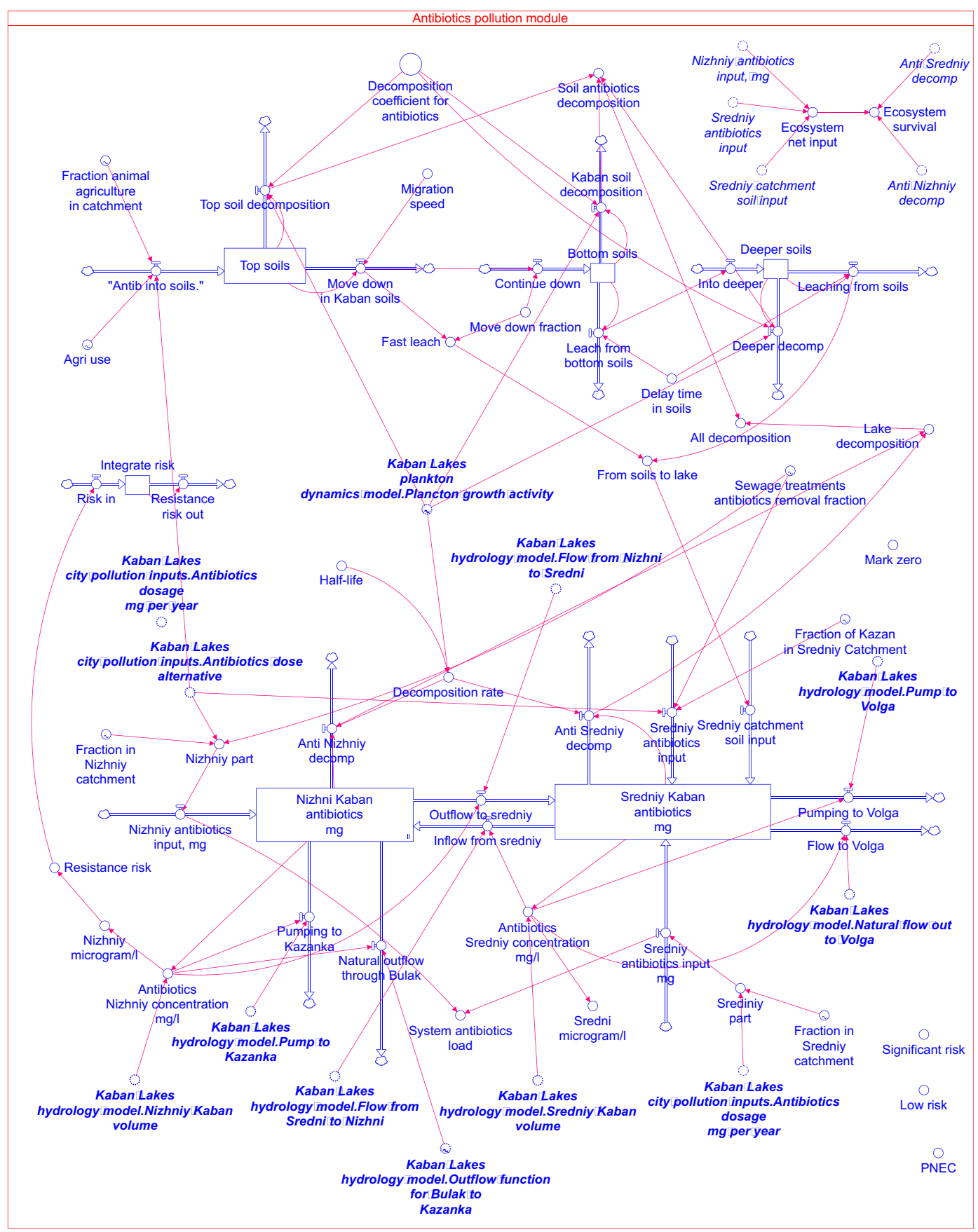

Fig. 6 Overview of the antibiotic module in the integrated structure (Fig. 5)

in the aqueous phase (de Vries et al. 1998, Bakker et al. 1998, Chapra 1991). We have assumed that it decomposes in the aqueous phase and in the adsorbed phase. This we assume based on the fact that the antibiotics absorb the most to organic matter (Chapra 1991), that the organic matter in itself gets decomposed, and that the antibiotic gets digested with it (Chapra 1991; Chapra and Reckhow 1983). Figure 8 shows some of the feedback functions used in the model for different processes described in the text. These curves serve instead of 
Fig. 7 Estimated antibiotic inputs to the Kaban lakes. See the text for explanation of how this was estimated (Sverdrup et al. 2020)

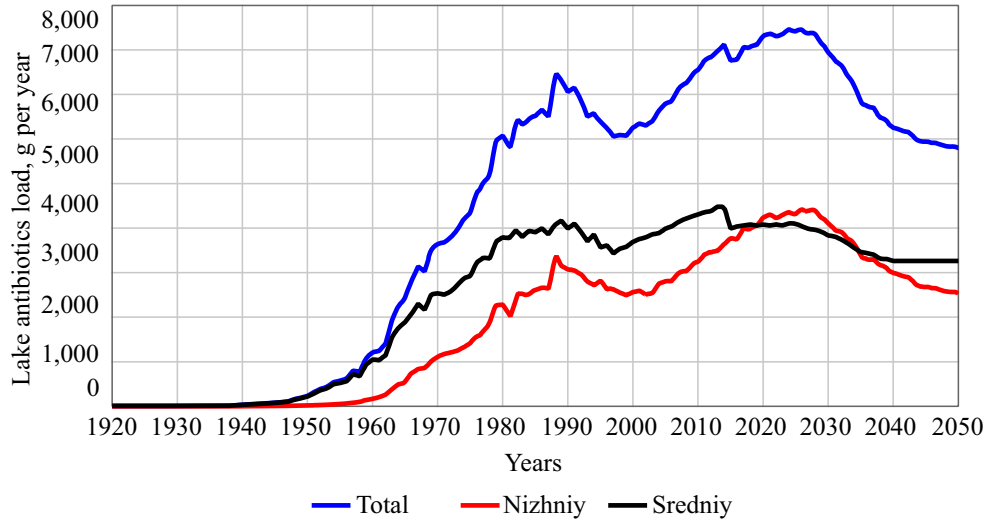

equations and are typical of the system dynamics methodology. They allow for the use of empirically observed feedback relationships.

\section{Results}

The results of the simulations have been shown in Figs. 9, 10, 11, and 12. Figure 9 shows the simulation results for antibiotic concentration in the lakes for 2016 to 2020 . There is a buildup of the concentration during the winter with low temperatures in the water and a quick decomposition in the summer, when the concentrations go down. The terms PNEC $(0.1 \mu \mathrm{g} / \mathrm{l})$, low risk $(0.3 \mu \mathrm{g} / \mathrm{l})$, and significant risk $(1 \mu \mathrm{g} / \mathrm{l})$ are limits recommended by EU and WHO. The antibiotic concentration levels in both Kaban lakes appear to be above what is considered a safe level of $0.1 \mu \mathrm{g} / \mathrm{l}$, in Nizhniy Kaban lake during certain parts of the year (Fig. 10) and in Sredniy Kaban lake all the time (Fig. 11). The variation in the signal is mainly caused by the seasonal variations in flow and temperature. Low risk is a limit where the effects have been evaluated to low or at the no observed effect concentration (NOEC) limit, and the significant risk is where some effect seems likely. The low-risk line should not be transgressed if the lake is used for bathing. The PNEC limit of $0.1 \mu \mathrm{g} / \mathrm{l}$ is required if the water body is to be used for drinking water (WHO 2011). Some countries demand half the PNEC limit, $0.05 \mu \mathrm{g} / \mathrm{l}$. The term PNEC is defined as follows: proposed no effect concentration. They are based on being set below the NOEC: the no observed effect concentration; these are the studies that sometimes have run for many years (WHO 2011; 2015a, b). Some antibiotics are decomposed in the lake after arrival, a significant amount in the warm period.

Figure 12 shows the net decomposition of antibiotics in both Kaban lakes, including the decomposition in the soils in the catchments. The annual variation in the signal is caused by the seasonal variations in flow and temperature; the amplitude trend is caused by the rise and decline in the antibiotic load to the lake system. During peak decomposition, larger amounts of antibiotics are decomposed than what is added through lake pollution inflow. This cause is a negative value and there is net antibiotic removal. During the cold period of the year, the decomposition is significantly less and the decomposition will be significantly less than the inflow.

\section{Discussion}

The model simulation results shown here are made making a lot of assumptions concerning the input data and the parameterization. Many of the key inputs are known in outline only and had to be estimated making assumptions with significant uncertainty, using experience and state-of-the-art approaches (Chapra 1991; Chapra and Reckhow 1983; Barkman et al. 1994). The conclusions based on the predictions are uncertain and must be used with great caution. No survey of antibiotic pollution known to us has been made in the Kaban lake system. However, the results do show that further investigation of the Kaban lakes system is justified and probably necessary.

The generalized results are consistent with the findings in other studies (Boxall and Wilkinson 2019; 

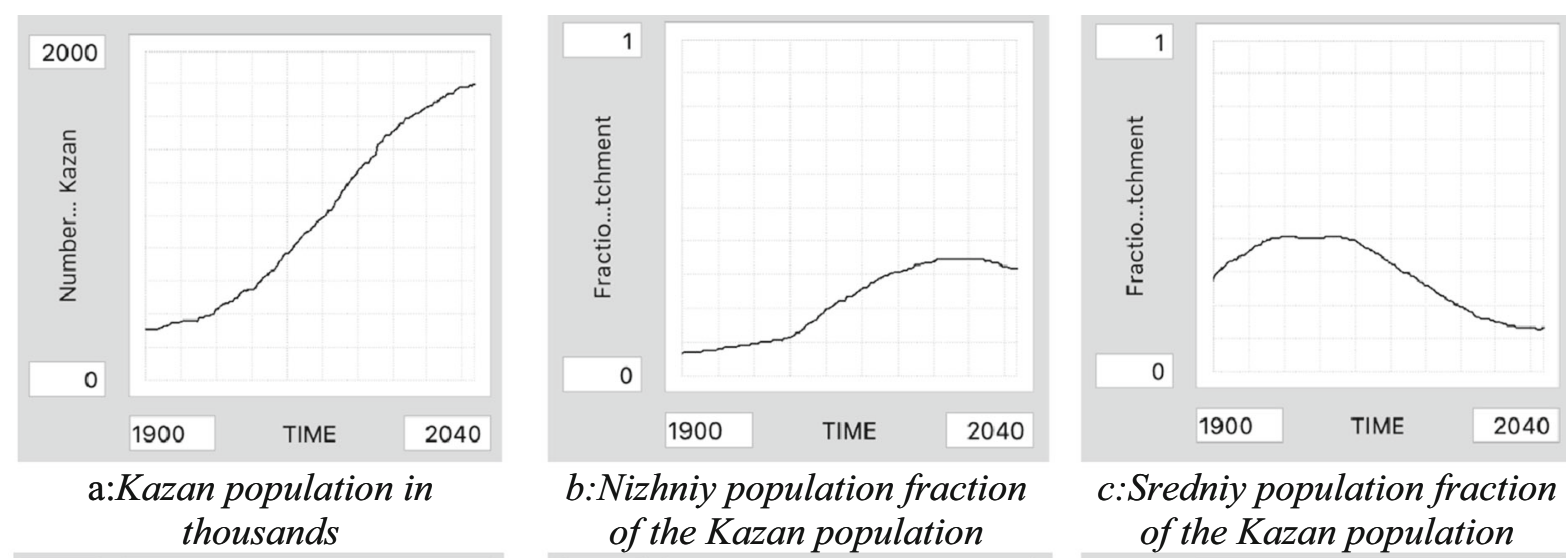

b:Nizhniy population fraction

c:Sredniy population fraction

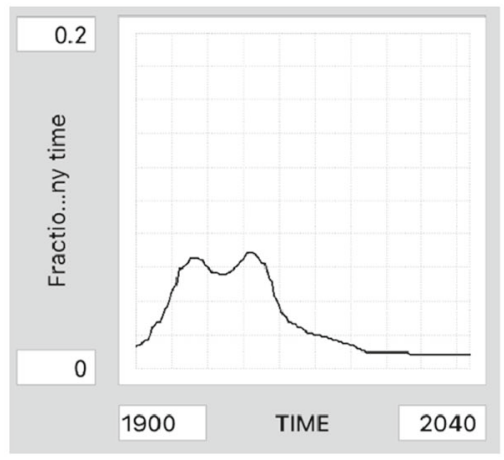

d:Fraction ill at any time

\section{of the Kazan population}

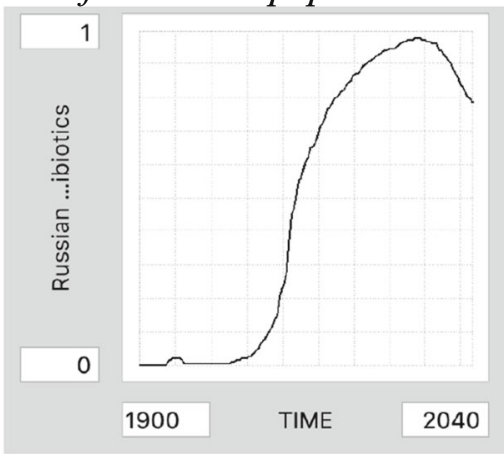

e: Russian antibiotics use scaling with time

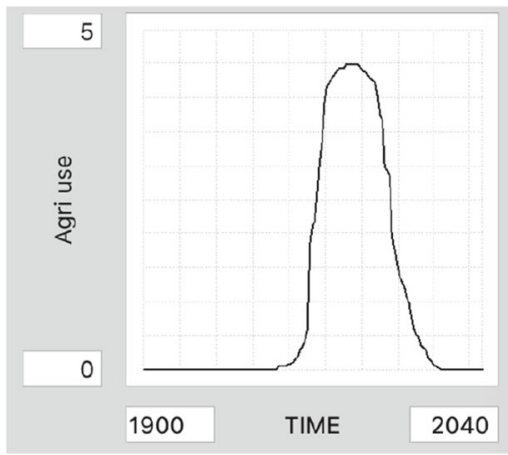

g: agricultural use in times of the medical volume

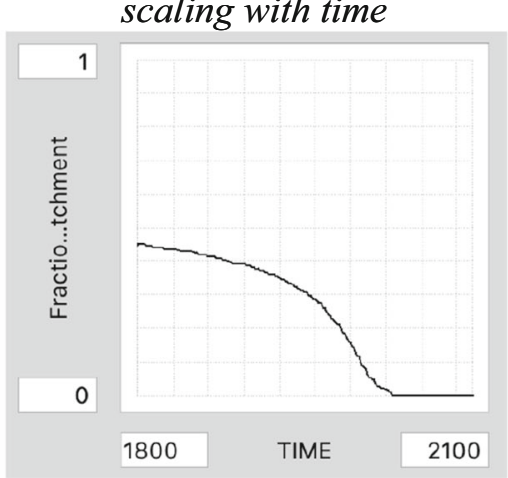

h: Fraction of the catchment with animal husbandry agriculture in Kaban

\section{of the Kazan population}

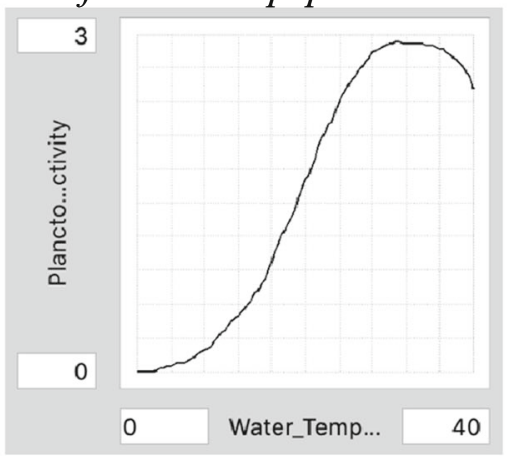

f:Decomposition activity

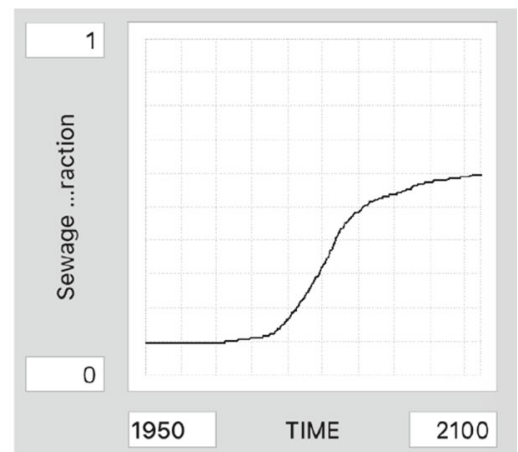

$i$ : Sewage treatment antibiotics removal
Fig. 8 Feedback functions used in the model for different processes described in the text. a Kazan population in thousands. b Nizhniy population fraction of the Kazan population. c Sredniy population fraction of the Kazan population. d Fraction ill at any

Wilkinson and Boxall 2019; Gilbert 2019) and our assessment for the Volga River. The literature (Ratchina 2015; Obukhova and Lartseva 2014, 2018; Belkova et al. 2012; 2013) suggests that there may be an antibiotic issue with the Volga River, which we time. e Russian antibiotic use scaling with time. f Decomposition activity. g Agricultural use in times of the medical volume. $\mathbf{h}$ Fraction of the catchment with animal husbandry agriculture in Kaban. i Sewage treatment antibiotics removal

confirmed in our earlier study (Sverdrup et al. 2020). However, very little literature is available in the scientific literature on this aspect of the Kaban lake system (Sverdrup et al. 2020). 

antibiotic concentration in the lakes. 3 PNEC suggested by the WHO, 4 low risk for antibiotic resistance line, 5 high risk for antibiotic resistance line. The limits are the adaptations from the WHO guidelines $(2011,2015 \mathrm{a}, \mathrm{b})$
Fig. 9 The simulation results for

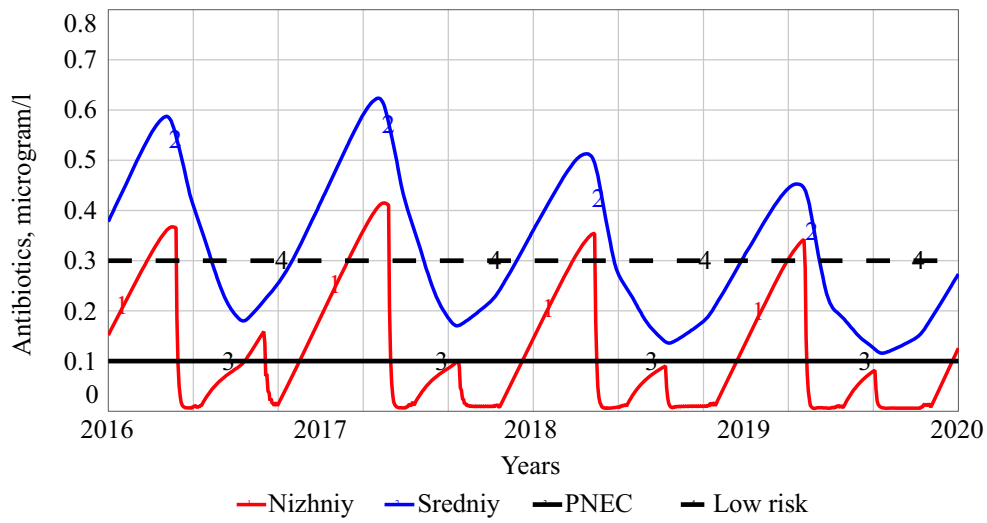

Fig. 10 Shows the Sredniy Kaban lake concentration of antibiotics. The terms PNEC ( 0.1 microgram/l), low risk $(0.3$ microgram/l) and significant risk (1 microgram/l) are limits recommended by EU and WHO. The antibiotics concentration level in Sredniy Kaban lake appear to be above what is considered a safe level for most of the year.

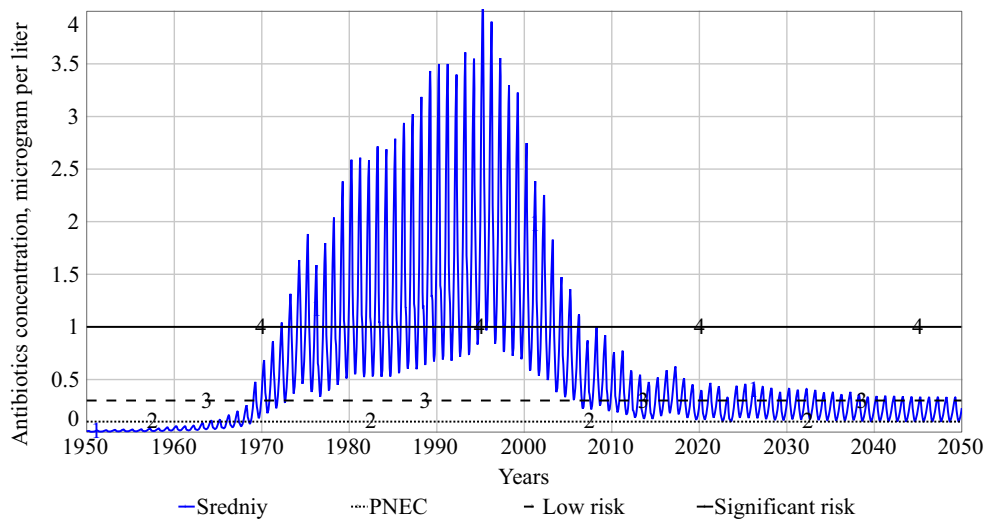

If antibiotics really are a problematic situation at the Kaban lakes, it could not be verified by a comparison with empirical data from the Kaban lakes, as we found no such measurements in the reports available to us. If the general principles used for Volga are relevant for the
Kaban lakes (we think it is), then that supports that there is possibly an issue for the Kaban lakes system. But only water sampling and actual measurements can tell.

The decomposition in the soil and decomposition in the water vary with the temperature (Chapra 1991,
Fig. 11 Shows the Nizhniy Kaban lake concentration of antibiotics. The terms PNEC $(0.1 \mu \mathrm{g} / \mathrm{l})$ and low risk $(0.3 \mu \mathrm{g} / \mathrm{l})$ are limits recommended by EU and WHO. The antibiotic concentration level in Nizhniy Kaban lake exceeds the PNEC limit and the low risk occasionally.

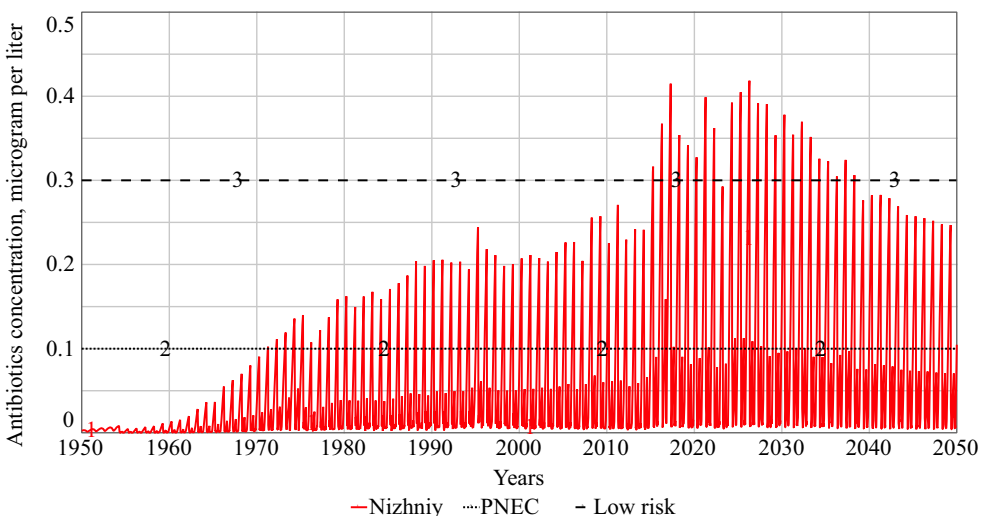


Fig. 12 The decomposition of antibiotics in both Kaban lakes, including the catchments. During peak decomposition, more is decomposed than what is added through pollution inflow

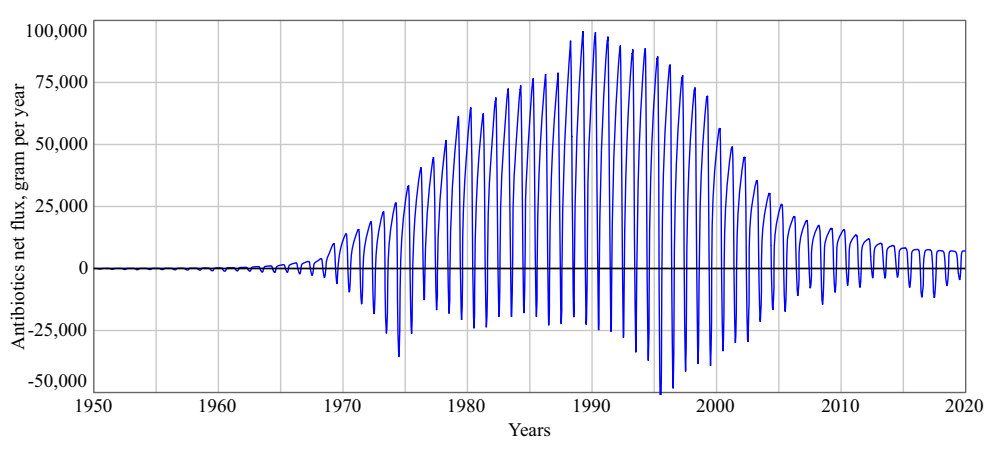

Sverdrup et al. 2002, 2020. The simulated concentrations are significantly lower in the warm period of the year and higher in the cold period. In the cold period, the decomposition in the lakes and in the soils will be very low.

\section{Conclusions}

The study suggests that the antibiotic concentration in the Nizhniy Kaban and Sredniy Kaban lakes may be above the limits proposed by the WHO and the EU for no effect concentration (PNEC). Our simulations involve many assumptions and guesswork for substitution missing data and the predictions are thus very uncertain. The simulations show clearly that such calculations are possible, and the missing point now is an access to better data. Thus, they are suggestive of what may be taking place, but with no certainty that this is really so. More measurements are needed on antibiotic loads and pathways of substances from the sewage to the lakes, in order to make better simulations and future risk assessments. The results as shown in Figs. 9, 10, 11, and 12 would make us suggest that such measurements are made during several parts of the year.

\footnotetext{
Acknowledgments This work was developed as a part of the strategic research being done at the Genetics and Bioinformatics, Kazan Federal University, Kazan, Russia, and Gamification and Systems Thinking at the Inland Norway University of Applied Sciences, Hamar, Norway. Dr. Ullrich Lorenz is project officer at the German Environmental Protection Agency (UBA), Dessau. It contributes to the EU 2020 LOOMOTION (Building a Lowcarbon, Climate Resilient Future: Climate Action in Support of the Paris Agreement (H2020-LC-CLA-2018-2) project. The project coordinator is Dr. Luis Javier Miguel Gonzales, at Industrial Engineering, University of Valladolid, Valladolid, Spain.
}

Funding Information Open Access funding provided by Inland Norway University Of Applied Sciences. It is a part of the overall strategy of the development of the WORLD7 model, supported by the SIMRESS grant (funded by the German Federal Ministry for Environment and the German Environmental Protection Agency (FKZ 371293 102).

Open Access This article is licensed under a Creative Commons Attribution 4.0 International License, which permits use, sharing, adaptation, distribution and reproduction in any medium or format, as long as you give appropriate credit to the original author(s) and the source, provide a link to the Creative Commons licence, and indicate if changes were made. The images or other third party material in this article are included in the article's Creative Commons licence, unless indicated otherwise in a credit line to the material. If material is not included in the article's Creative Commons licence and your intended use is not permitted by statutory regulation or exceeds the permitted use, you will need to obtain permission directly from the copyright holder. To view a copy of this licence, visit http://creativecommons.org/licenses/by/4.0/.

\section{References}

Aarestrup, F. M., Seyfarth, A. M., Emborg, H.-D., Pedersen, K., Hendriksen, R. S., \& Bager, F. (2001). Effect of abolishment of the use of antimicrobial agents for growth promotion on occurrence of antimicrobial resistance in fecal enterococci from food animals in Denmark. Antimicrobial Agents and Chemotherapy, 45, 2054-2059.

Aherne, G. W., Hardcastle, A., \& Nield, A. H. (1990). Cytotoxic drugs and the aquatic environment: estimation of bleomycin in river and water samples. Journal of Pharmacy and Pharmacology, 42, 741-742.

Albin, S. (1997). Building a system dynamics model; Part 1; Conceptualization. MIT System Dynamics Education Project (J. Forrester (Ed)). MIT, Boston. 34 pp. https://ocw. mit.edu/courses/sloan-school-of-management/15-988system-dynamics-self-study-fall-1998-spring-1999 /readings/building.pdf.

Alder, A. C., et al. (2006). Consumption and occurrence. In T. A. Ternes \& A. Joss (Eds.), Human pharmaceuticals, hormones and fragrances: the challenge of micropollutants in urban water management. London: IWA Publishing. 
Aldeyab, M. A., Monnet, D. L., López-Lozano, J. M., Hughes, C. M., Scott, M. G., Kearney, M. P., Magee, E. A., \& McElnay, J. C. (2008). Modelling the impact of antibiotic use and infection control practices on the incidence of hospitalacquired methicillin-resistant Staphylococcus aureus: a time-series analysis. Journal of Antimicrobial Chemotherapy, 62, 593-600.

Allen, H. K., Donato, J., Wang, H. H., Cloud-Hansen, K. A., Davies, J. E., \& Handelsman, J. (2010). Call of the wild: antibiotic resistance genes in natural environments. Nature Reviews Microbiology, 8, 251-259.

Andersson, D. I. (2006). The biological cost of mutational antibiotic resistance: any practical conclusions? Current Opinion in Microbiology, 9, 461-465.

ANSES (2011). Campagne nationale d'occurrence des résidus de médicaments dans les eaux destinées à la consommation humaine. Ressources en eaux brutes et eaux traitées. Nancy, Agence nationale de sécurité sanitaire de l'alimentation, de l'environnement et du travail, Laboratoire d'Hydrologie de Nancy.

Ashton, D., Hilton, M., \& Thomas, K. V. (2004). Investigating the environmental transport of human pharmaceuticals to streams in the United Kingdom. Science of the Total Environment, 333, 167-184.

Bakker, D., de Vries, W., Sverdrup, H. 1998. Effects-based approaches to assess the risk of heavy metal inputs to surface waters-Overview methods and models. In: Workshop on critical limits and effect based approaches for heavy metals and persistent organic pollutants, Gregor, H., Spranger, T., Hörnerbach, F. (eds). Umweltbundesamt Texte 5, 98:225-278.

Barkman, A., Sverdrup, H. (1994) Biomanipulation as a tool for mitigating eutrophication. Modeling the case study lake Finjasjön in southern Sweden. In: S. Jörgensen (Ed) Proceedings of the International Symposium on Ecosystems Manipulation, 234-255, Windermere, England.

Barkman, A., Sverdrup, H., Hamrin, H., (1994). Biomanipulation for mitigating eutrophication. Modelling the case study of lake Finjasjøn in Southern Sweden. In: Jenkins, A., Ferrier, B., Kirby, C., pages 286-288.

Behdinan, A., \& Hoffman, S. J. (2015). Some global strategies for antibiotic resistance require legally binding and enforceable commitments. The Journal of Law, Medicine \& Ethics, $43(2)$.

Belkova Y. et al. (2012). Assessment of systemic antimicrobials use and expenditures in Russian multi-profile hospitals: the results of multicenter trial. Proceedings of the 15th ICID. Bangkok, Thailand, June 13-16, 2012.

Belkova Y. A. et al. (2013). Systemic antimicrobials consumption and expenditures in Russian multi-profile hospitals: the results of multicenter trial. Proceedings of the 23nd ECCMID. Berlin, Germany, April 27-30.

Binder, T., Vox, A., Belyazid, S., Haraldsson, H., Svensson, M., (2003). Developing system dynamics models from causal loop diagrams. 21 pp. https://www.semanticscholar.org/, https://pdfs.semanticscholar.org/cf00/b9084b05ba357bf0c5 fa7a5b9cc1b5695015.pdf.

Boxall, A., and Wilkinson, J. (2019). Identifying hotspots of resistance selection from antibiotic exposure in urban environments around the world. SETAC Europe 29th Annual Meeting, Helsinki, May 27, 2019.
Brown, E. M., \& Nathwani, D. (2005). Antibiotic cycling or rotation: a systematic review of the evidence of efficacy. Journal of Antimicrobial Chemotherapy, 55, 6-9.

Cassini, A., Högberg, L. D., Plachouras, D., Quattrochi, A., Hoxcha, A., Skov-Simonsen, G., Colomb-Cotinat, M., Kretzschmar, M. E., Devleesschauwer, B., Cecchini, M., Ouakrim, D. A., Oliviera, T. C., Struelens, M. J., Suetens, C., \& Monnet, D. L. (2019). Attributable deaths and disability-adjusted life-years caused by infections with antibiotic-resistant bacteria in the EU and the European Economic Area in 2015: a population-level modelling analysis. Lancet Infectious Diseases, 19, 56-66.

Cassir, N., Rolain, J. M., \& Brouqui, P. (2014). A new strategy to fight antimicrobial resistance: the revival of old antibiotics. Frontiers in Microbiology, 5, 551. https://doi.org/10.3389 /fmicb.2014.00551.

Castiglioni, S., et al. (2006). Removal of pharmaceuticals in sewage treatment plants in Italy. Environmental Science \& Technology, 40, 357-363.

Ceccini, M., Langer, J., Slawomirski, L. (2015). Antimicrobial resistance in G7 countries and beyond: Economic Issues, Policies and Options for Action. OECD. 75 pp.

Chapra, S. C. (1991). Lake and water quality and modelling workshop, NALMS 11th International Symposium, Denver Colorado, Nov 15, 1991, Center for advanced decision support for water and environmental systems.

Chapra S. C. and Reckhow K. H. (1983). Engineering approaches for lake management-Volume I. Prentice-Hall.

Chee-Sanford, J. C., Mackie, R. I., Koike, S., Krapac, I. G., Lin, Y.-F., Yannarell, Y. C., Maxwell, S., \& Aminov, R. I. (2009). Fate and transport of antibiotic residues and antibiotic resistance genes following land application of manure waste. Journal of Environmental Quality, 38, 1086-1108. https://doi.org/10.2134/jeq2008.0128.

Cogliani, C., Goossens, H., \& Greko, C. (2011). Restricting antimicrobial use in food animals: lessons from Europe. Microbe, 6, 274-280.

Cycon, M. C., Mrozik, A., \& Piotrowska-Segel, Z. (2019). Antibiotics in the soil environment - degradation and their impact on microbial activity and diversity. Frontiers in Microbiology, 10, 338-382.

Davies, J., \& Davies, D. (2010). Origins and evolution of antibiotic resistance. Microbiology and Molecular Biology Reviews, 74, 417-433.

de Kraker, M. E. A., Stewardson, A. J., \& Harbarth, S. (2016). Will 10 million people die a year due to antimicrobial resistance by 2050? PLoS Medicine, 13, e1002184.

de Vries, W., Bakker, D., Sverdrup, H., Paces, T., Tipping, T. (1998). Effects-based approaches to assess the risk of heavy metal inputs to soils-overview methods and models. In: Workshop on critical limits and effect based approaches for heavy metals and persistent organic pollutants, H. Gregor, T. Spranger, F. Hörnerbach (Eds). Umweltbundesamt Texte 5: 98:125-224 issn 0722-186X.

Derevenskaya, O. Y., Mingazova, N. M., \& Pavlova, L. R. (2015). Lake water quality of Kazan city (Russia) Kaban lake in the anthropogenic pollution conditions and improving actions implementation. International Journal of Applied Engineering Research, 10, 44,682-44,687.

Domagk, G. 1935 Eine neue Klasse von Desinfektionsmitteln. Deutche Medicinische Wochenschrift. 61, 250-253. 
Dunaev, I. I. (1833). Results of chemical analysis of Volga and Kaban water. Zavolzhsky Ant, 3, 1149.

Economou, V., \& Gousia, P. (2015). Agriculture and food animals as a source of antimicrobial-resistant bacteria. Infection and Drug Resistance., 8, 49-61. https://doi.org/10.2147/IDR. S55778.

Emerson de Lima Procopio, R., Reis da Silva, I., Martins, M. K., Lucioo de Zevedo, J., \& Magali de Araujo, J. (2012). Antibiotics produced by streptomycetes. The Brazilian Joyrnal of Infectuous Diseases, 16, 466-471.

ESAC Yearbook (2009). Available from: http://ecdc.europa. e u/en/a ctivities/surveillance/ES A C Net/publications/Documents/.

Fair, R. J., \& Tor, Y. (2014). Antibiotics and bacterial resistance in the 21 st century. Perspectives in Medicinal Chemistry, 6, 2564.

Filtzer, D. (2008). Poisoning the Proletariat: Urban water supply and river pollution in Russia's industrial regions during Late Stalinism, 1945-1953. Acta Slavica Iaponica, 26, 85-108.

Fleming, A. (1929). On the antibacterial action of cultures of a penicillium, with special reference to their use in the isolation of $B$. influenzae. Bulletin of the World Health Organization, 79, 780-790.

Fokin, A. A. et al. (2011). Patterns of antimicrobials usage in surgical infection units in 5 Russian cities. Proceedings of the 27th ICPE, Chicago, USA, August 14-17, 2011.

Forrester, J. W. (1971). World dynamics. Waltham: Pegasus Communications.

Gabdulhakova, O. I., Lukyanova, A. V., \& Stratilatova, I. I. (2016). Social and ecological risks of the petrochemical industry development. Journal of Environmental Management \& Tourism, 7, 399-406. https://doi. org/10.14505/jemt.v7.3(15).05.

Gaynes, R. (2017). The discovery of penicillin - new insights after more than 75 years of clinical use. Emerging Infectious Diseases, 23, 849-853.

Gilbert, N. (2019). World's rivers 'awash with dangerous levels of antibiotics. Largest global study finds the drugs in two-thirds of test sites in 72 countries. Guardian, Monday, 27. May, Newspaper article referring to an article forthcoming in the Lancet. https:/www.theguardian.com/society/2019/may/27 /worlds-rivers-awash-with-dangerous-levels-of-antibiotics.

Gilchrist, M. J., Greko, C., Wallinga, D. B., Beran, G. W., Riley, D. G., \& Thorne, P. S. (2006). The potential role of concentrated animal feeding operations in infectious disease epidemics and antibiotic resistance. Environmental Health Perspectives, 115, 313-316.

Gore, A.C., Chappell, V.A., Fenton, S.E., Flaws, J.A., Nadal, A., Prins, G.S., Toppari, J., Zoeller, R.T. 2015. Executive Summary to EDC-2: The Endocrine Society's Second Scientific Statement on Endocrine-Disrupting Chemicals. Endocrine Reviews. 36, 593-602.

Gorelits, O., \& Zemyanov, I. (2017). The Volga River Basin history of development and modern hydrological regime under the changing climate. Federal Service on Hydrometeorology and Environmental Monitoring of the Russian Federation Zubov State Oceanographic Institute Italia, Conference powerpoint presentation, Hydrological Conference Roma, 24(10), 2017.

Greenfield, B. K., Shaked, S., Marrs, C. F., Nelson, P., Raxter, I., Xi, C., McKone, T. E., \& Jolliet, O. (2018). Modeling the emergence of antibiotic resistance in the environment: an analytical solution for the minimum selection concentration. Antimicrobial Agents and Chemotherapy, 62, e01686e01617. https://doi.org/10.1128/AAC.

Gualerzi, C. O., Brandi, L., Fabbretti, A., \& Pon, C. L. (2013). Antibiotics: targets, mechanisms and resistance. Wiley ISBN 9783527333059.

Halling-Sørensen, B., Nors Nielsen, S., Lansky, P. E., Ingerslev, F., Holten Lützhøft, H. C., \& Jørgensen, S. E. (1998). Occurrence, fate and effects of pharmaceutical substances in the environment - a review. Chemosphere, 36, 357-393.

Haraldsson, H. (2004). Introduction to systems thinking and causal loop diagrams. Reports in Ecology and Environmental Engineering 1:2004 (5th ed.). Lund: Lund University.

Haraldsson, H., and Sverdrup, H., (2005). On aspects of systems analysis and dynamics workflow. Proceedings of the systems dynamics society, July 17-21, 2005 International Conference on systems dynamics, Boston, USA. 10 pages. http://www. s y s t e m d y n a m i c s.org/con ferences/2005 /proceed/papers/HARAL310.pdf.

Heberer, T., Schmidt-Bäumler, K., \& Stan, H. J. (1998). Occurrence and distribution of organic contaminants in the aquatic system in Berlin. Part II: Substituted phenols in Berlin surface water. Acta Hydrochimica et Hydrobiologica, 26, 272-278.

Heilig, S., Lee, P., \& Breslow, L. (2002). Curtailing antibiotic use in agriculture. It is time for action: this use contributes to bacterial resistance in humans. Western Journal of Medicine, 176, 9-11.

Heinemann, J. A., Ankenbauer, R. G., \& Amábile-Cuevas, C. F. (2000). Do antibiotics maintain antibiotic resistance? Drug Discovery Today, 5, 195-204.

Higuera-Llantén, S., Vásquez-Ponce, F., Barrientos-Espinoza, B., Mardones, F. O., Marshall, S. H., \& Olivares-Pacheco, J. (2018). Extended antibiotic treatment in salmon farms select multi-resistant gut bacteria with a high prevalence of antibiotic resistance genes. PLoS ONE, 13(9), e0203641. https://doi.org/10.1371/journal.pone.0203641.

Hurd, H. S., Doores, S., Hayes, D., Mathew, A., Maurer, J., Silley, P., Singer, P. S., \& Jones, R. N. (2004). Public health consequences of macrolide use in food animals: a deterministic risk assessment. Journal of Food Protection, 67(5), 980-989.

Interagency Coordination Group on antimicrobial resistance (2019). No time to wait: securing the future from drugresistant infections. Report to the Secretary-General of the United Nations, UN, New York, 28 pages.

Kalimullin, A. M. (2005). Environmental issues in context of industrial growth of Tatarstan Republic in the late 1960thearly 1990th. Kazan University.

Kalimullin, A. M., and Vinogradov, V. V. (2015). Ecological and sanitary problems of Kazan Province industrial development in the XIX ${ }^{\text {th }}$ and early XX $^{\text {th }}$ centuries Review of European Studies; Vol. 7, No. 1; 2015 ISSN 1918-7173.

Kim, D. H. (1992). Toolbox: guidelines for drawing causal loop diagrams. The Systems Thinker, 3, 5-6.

Klein, E. Y., van Broeckel, T. P., Matinez, E. M., Pant, S., Gandre, S., Levin, S., Goossens, H., \& Laxminarayan, R. (2017). Global increase and geographic convergence in antibiotic consumption between 2000 and 2015. Proceedings of the National Academy of Sciences, 115, E3463-E3470. 
Krestovnikov, N. K. (1870). Industry and trade turnovers of Kazan. Kazan University Report.

Landers, T., Cohen, B., Wittum, T. E., \& Larson, E. L. (2012). A review of antibiotic use in food animals: perspective, policy, and potential. Public Health Reports, 127, 4-23.

Laxminarayan, R., Duse, A., Wattal, C., Zaidi, A. K., Wertheim, H. F., Sumpradit, N., Vlieghe, E., Hara, G. L., Gould, I. M., Goossens, H., Greko, C., So, A. D., Bigdeli, M., Tomson, G., Woodhouse, W., Ombak, A. E., Peralta, A. Q., Qamar, F. N., Mir, F., Kariuki, S., Bhutta, Z. A., Coates, A., Bergstrom, R., Wright, G. D., Brown, E. D., \& Cars, O. (2013). Antibiotic resistance-the need for global solutions. The Lancet. Infectious Diseases., 13, 1057-1098.

Leekha, S., Terrell, C. L., \& Edson, R. S. (2011). General principles of antimicrobial therapy. Mayo Clinic Proceedings, 86, 156-167. https://doi.org/10.4065/mcp.2010.0639.

Ling, L. L., Schneider, T., Peoples, A. J., Spoering, A. L., Engels, I., Conlon, B. P., Mueller, A., Schäberle, T. F., Hughes, D. E., Epstein, S., Jones, M., Lazarides, L., Steadman, V. A., Cohen, D. R., Felix, C. R., Fetterman, K. A., Millett, W. P., Nitti, A. G., Zullo, A. M., Chen, C., \& Lewis, K. (2015). A new antibiotic kills pathogens without detectable resistance. Nature, 517, 455-459.

Lyons, G. (2014). Pharmaceuticals in the environment: a growing threat to our tap water and wildlife. A CHEM Trust report 36 pages.

Marshall, B. M., \& Levy, S. B. (2011). Food animals and antimicrobials: impacts on human health. Clinical Microbiology Reviews, 24, 718-733.

Meadows, D. L., Behrens III, W. W., Meadows, D. H., Naill, R. F., Randers, J., \& Zahn, E. K. O. (1974). Dynamics of Growth in a Finite World. Massachusetts: Wright-Allen Press, Inc..

Mingazova, N. N. (1999). The anthropogenous change and restoration of small lakes ecosystems (on an example of the Middle Volga region) - The dissertation on competition of a scientific degree of Dr.Sci.Biol. St.-Petersburg University of Saint Petersburg, Russia.

Mingazova, N., Derevenskaya, O., Barieva, E., Pavlova, L. (2019). Restoration of Low Kaban Lake (Kazan, Russia): 25-term experience of restoration and monitoring of ecological condition. 7 pages. https://www.researchgate. net/publication/264890587.

Moisenko, N. N. (1994). Antibiotic-resistant enterobacteria in sewage and the water of surface reservoirs. Antibiotiki $i$ Khimioterapiia, 39, 64-68.

Obukhova, O. V., \& Lartseva, L. V. (2014). Features of antibiotic resistance of enterobacteria in the Volga River delta. Gigiena $i$ Sanitariia, 3, 21-23.

Obukhova, O. V., \& Lartseva, L. V. (2018). Ecological characteristics of antibiotic resistance of conditionally pathogenic microorganisms persistent in hydroecosystems. Vestnik of Astrakhan State Technical University. Series: Fishing Industry, 53-57. https://doi.org/10.24143/2073-5529-20184-53-57.

Paxéus, N. (2004). Removal of selected non-steroidal anti-inflammatory drugs (NSAIDs), gemfibrozil, carbamazepine, $\beta$ blockers, trimethoprim and triclosan in conventional wastewater treatment plants in five EU countries and their discharge to the aquatic environment. Water Science and Technology, 50, 253-260.
Penesyan, A., Gillings, M., \& Paulsen, I. (2015). Antibiotic discovery: combatting bacterial resistance in cells and in biofilm communities. Molecules, 2015(20), 5286-5298.

Phillips, I., Casewell, M., Cox, T., de Groot, B., Friis, C., Jones, R., Nightingale, C., Preston, R., \& Waddell, J. (2003). Does the use of antibiotics in food animals pose a risk to human health? A critical review of published data. Journal of Antimicrobial Chemotherapy, 53, 28-52.

Podolsky, S. H. (2018). The evolving response to antibiotic resistance (1945-2018). Palgrave Communications, 4, 124-132. https://doi.org/10.1057/s41599-018-0181-x www.nature. com/palcomms.

Price, L. B., Koch, B. J., \& Hungate, B. A. (2015). Ominous projections for global antibiotic use in food-animal production. Proceedings of the National Academy of Sciences, 112, $5554-5555$

Ratchina, S. (2015). Antibiotic use surveillance in Russia: current state and prospects for collaboration, Moscow, 18 December, 2015. 23 pages ppt presentation. Inter-regional Association for Clinical Microbiology \& Antimicrobial Chemotherapy, Smolensk, Russian Federation.

Ratchina, S. A. et al. (2009). Optimization of systemic antimicrobials usage in multi-profile hospitals in Russian Federation. Proceedings of the 19th ECCMID. Helsinki, Finland, May 16-19, 2009.

Roberts, N., Andersen, D. F., Deal, R. M., \& Shaffer, W. A. (1982). Introduction to Computer Simulation: A System Dynamics Approach Productivity Press. Chicago.

Sarmah, A. K., Meyer, M. T., \& Boxall, A. B. A. (2006). A global perspective on the use, sales, exposure pathways, occurrence, fate and effects of veterinary antibiotics (VA's) in the environment. Chemosphere, 65, 725-759.

Senge, P. (1990). The Fifth Discipline. The Art and Practice of the Learning Organisation. Century Business, New York.

Senge, P. M., Smith, B., Schley, S., Laur, J., \& Kruschwitz, N. (2008). The necessary revolution: How individuals and organisations are working together to create a sustainable World. London: Doubleday Currency.

Shea, K. M. (2003). antibiotic resistance: what is the impact of agricultural uses of antibiotics on children's health? Pediatrics., 112, 253-258.

Silbergeld, E. K., Graham, J., \& Price, L. B. (2008). Industrial food animal production, antimicrobial resistance, and human health. Annual Review of Public Health, 29, 151-169.

Sverdrup, H. and Stjernquist, I. (Eds.) (2002). Developing principles for sustainable forestry, results from a research program in southern Sweden. Managing Forest Ecosystems 5: 566 pages, Kluwer Academic Publishers, Amsterdam.

Sverdrup, H., Hagen-Thorn, A., Holmqvist, J., Warfvinge, P., Walse, C., Alveteg, M. (2002) Biogeochemical processes and mechanisms. In: Developing principles for sustainable forestry Results from a research program in southern Sweden. Sverdrup, H., and Stjernquist, I. (Eds.) Managing Forest Ecosystems 5:91-196. Kluwer Academic Publishers, Amsterdam

Sverdrup, H., Haraldsson, H., Olafsdottir, A.H., Belyazid, S. (Ed.) (2018) System thinking, system analysis and system dynamics: find out how the world works and then simulate what would happen. 3rd revised edition. Háskolaprent Reykjavik. 310 pp. ISBN 978-9935-24-425-3. 
Sverdrup, H. U., Frolova, L. L., \& Sverdrup, A. E. (2020). Using a system dynamics model for investigating potential levels of antibiotics pollution in the Volga River. Water, Air, and Soil Pollution, 231, 173. https://doi.org/10.1007/s11270-02004526-w.

Tan, S. Y., \& Tatsumura, Y. (2015). Alexander Fleming (18811955): Discoverer of penicillin. Singapore Medical Journal, 56, 366-367.

van Boeckel, T. P., Gandre, S., Ashok, A., Caudon, Q., Grenfell, B., Levin, S. A., \& Laxminarayan, R. (2014). Global antibiotic consumption 2000 to 2010: an analysis of national pharmaceutical sales data. Lancet, 14, 742-751.

van Boeckel, T. P., Brower, C., Gilbert, M., Grenfell, B. T., Levin, S. A., Robinson, T. P., Teillant, A., \& Laxminarayan, R. (2015). Global trends in antimicrobial use in food animals. Proceedings of the National Academy of Sciences, 112, 5649-5654.

van Bunnik, B. A. D., \& Woolhouse, M. E. J. (2017). Modelling the impact of curtailing antibiotic usage in food animals on antibiotic resistance in humans. Royal Society Open Science, 4, 161067. https://doi.org/10.1098/rsos.161067.

Ventola, C. L. (2011). The Antibiotic Resistance Crisis. Pharmacy and Therapeutics., 40, 277-283.

Vieno, N. M., Tuhkanen, T., \& Kronberg, L. (2005). Seasonal variation in the occurrence of pharmaceuticals in effluents from a sewage treatment plant and in the recipient water. Environmental Science \& Technology, 39, 8220-8226.

Vishlenkova, E. A. (2005). Do not drink water from Kaban! Environmental crisis at 19th century Kazan. Native Land, 8, 94-96.

Walse, C., Berg, B., \& Sverdrup, H. (1998). Review and synthesis of experimental data on organic matter decomposition with respect to the effect of temperature, moisture and acidity. Environmental Review, 6, 25-40.

Watkinson, A. J., Murby, E. J., \& Costanzo, S. D. (2007). Removal of antibiotics in conventional and advanced wastewater treatment: implications for environmental discharge and wastewater recycling. Water Research, 41, 4164-4176.

Watkinson, A. J., Murby, E. J., Kolpin, D. W., \& Costanzo, S. D. (2009). The occurrence of antibiotics in an urban watershed: from wastewater to drinking-water. Science of the Total Environment, 407, 2711-2723.

Wegener, H. (2003). Antibiotics in animal feed and their role in resistance development. Current Opinion in Microbiology, 6, 439-445.

Wegener, H. C. (2012). A15 Antibiotic Resistance-Linking Human and Animal Health. In: Choffnes, E.R.; Relman, D.A.; Olsen, L.; Hutton, R.; Mack, A. Antibiotic Resistance - Linking Human And Animal Health: Improving Food Safety Through a One Health Approach Workshop Summary. Washington DC: National Academies Press. ISBN 978-0-309-25937-8. NBK114485.
WHO. (2011). Guidelines for drinking-water quality (4th ed.). Geneva: World Health Organization.

Wilkinson, J. and Boxall, A. (2019). The first global study of pharmaceutical contamination in riverine environments. SETAC Europe 29th Annual Meeting, Helsinki, May 28, 2019.

Woolhouse, M., Ward, M., van Bunnik, B., Farrar, J. (2015). Antimicrobial resistance in humans, livestock and the wider environment. Philosophical Transactions of the Royal Society. B 370, 20,140,083. https://doi.org/10.1098 /rstb.2014.0083.

World Health Organization (WHO) (2009). Global Health Risks. Mortality and burden of disease attributable to selected major risks. 70 pages. ISBN 97892 4,156,387 1. https://www.who. int/healthinfo/global_burden_disease/GlobalHealthRisks_ report_full.pdf.

World Health Organization (WHO) (2011). Pharmaceuticals in drinking water. WHO/HSE/WSH/11.05 49 pages.

World Health Organization (WHO) (2015a). Antibiotic Resistance http://www.who.int/mediacentre/factsheets/antibioticresistance/en/.

World Health Organization (WHO) (2015b). Global Action Plan on Antimicrobial Resistance. http://apps.who. int/iris/bitstream/10665/193736/1/9789241509763_eng.pdf.

World Health Organization (WHO) (2017). The world is running out of antibiotics, WHO report confirms. News release. https://www.who.int/news-room/detail/20-09-2017-theworld-is-running-out-of-antibiotics-who-report-confirms.

Zaffiri, L., Gardner, J., \& Toledo-Pereyra, L. H. (2012). History of Antibiotics. From Salvarsan to Cephalosporins. Journal of Investigative Surgery, 25, 67-77.

Zurek, L., \& Ghosh, A. (2014). Insects represent a link between food animal farms and the urban environment for antibiotic resistance traits. Applied and Environmental Microbiology, 80, 3562-3567. https://doi.org/10.1128/AEM.00600-14.

These publications are being prepared but have not yet reached publication: Frolova et al. 2020a. Developing a system dynamics model for the Nizhniy and Sredniy Kaban lakes, assessing the impacts of phosphorus and nitrogen inputs to the lakes. 21 pages. Frolova et al. 2020b. Modelling the hydrology dynamics of the Nizhniy and Sredniy Kaban lakes. 21 pages. Sverdrup et al. 2020. Modelling global mortality dynamics including infectious disease, environmental pollution, nutrition, health status and the use of antibiotics in health care and agriculture. 31 pages

Publisher's Note Springer Nature remains neutral with regard to jurisdictional claims in published maps and institutional affiliations. 